\title{
The Role of Masyarakat Peduli Api (MPA) Communities in Forest and Land Fire Disaster Communication in Riau Province Case Study in Siak District in 2019
}

\author{
Adhianty Nurjanah ${ }^{1, *}$ Sakir $^{2}$, Aswad Ishak ${ }^{3}$ \\ ${ }^{1}$ Department Communication Science, Universitas Muhammadiyah Yogyakarta, Indonesia \\ ${ }^{2}$ Department Government Science, Universitas Muhammadiyah Yogyakarta, Indonesia \\ ${ }^{3}$ Department Communication Science, Universitas Muhammadiyah Yogyakarta, Indonesia \\ *Corresponding author. Email: adhianty@umy.ac.id
}

\begin{abstract}
Disasters occur unexpectedly, with varying severity, posing major challenges for effective information exchange and coordination. Forest and land fires are part of natural disasters that cause huge losses to both health and the economy. Forest fires in Siak Regency, Riau Indonesia continue every year. To save many victims, it requires cooperation between the government and the role of the community. This study aims to determine the role of Masyarakat Peduli Api (MPA) in Disaster Communication in Siak Regency, Riau. Indonesia.This study used a qualitative descriptive method and conducted in-depth interviews with the Regional Disaster Management Agency (BPBD) and Masyarakat Peduli Api (MPA) Community. The results showed that the role of Masyarakat Peduli Api Community was one of the supporting factors in the successful communication of forest and land fire disaster management in reducing the number of casualties. The role of the Masyarakat Peduli Api (MPA) is (1) Providing information regarding the location of the incident, (2) Disseminating information to village communities regarding forest fire disaster mitigation (prevention) and the impact of forest fires, (3) Conducting counselling, training and simulations forest fire disasters to the community with BPBD related to disaster mitigation and the introduction of the use of fire fighting equipment. Thus the Masyarakat Peduli Api (MPA) has an important role in disaster communication to the community and can minimize the loss of casualties and material and immaterial losses as a result of the forest fires that occur..
\end{abstract}

Keywords: Communication on Disasters, Forest Fires, Fire Concerned Community (MPA), Siak, Indonesia

\section{INTRODUCTION}

Disasters happen unexpectedly, with varying severity, posing major challenges for effective information exchange and coordination. Indonesia Forest and land fires are part of natural disasters that cause huge losses to both health and the economy. Forest fires in Siak Regency, Riau continue every year. To save many victims, it requires cooperation between the government and the role of the community. According Tirto.id on 2019 Land and forest fires in Riau Province have expanded to an area of 841.71 hectares (ha) throughout 2019 according to data from the local Regional Disaster Management Agency (BPBD). The total area burnt according to the Riau BPBD Data and Information
Center has surged by nearly 100 percent in the last three days. As of February 15, 2019, the total area of land burned was around 497 hectares [1].

Based on the results of research data with Secretary BPBD Siak Regency, Mr. Arif Hamidi, S.Sos., M.Si, said that Siak Regency has 13 Disaster-prone Districts and 71 Disaster-prone Villages. Districts that are prone to disasters include Siak, Sungai Apit, Minas, Kandis, Lubuh Dalam, Kerinci Kanan, Koto Gasib, Tualang, Sungai Mandau, Dayun, Bungraya, Mempura, Sabak Auh, Pusako districts. The largest contribution to disaster-prone villages is in Sungai Apit District, which consists of 14 disaster-prone villages. 


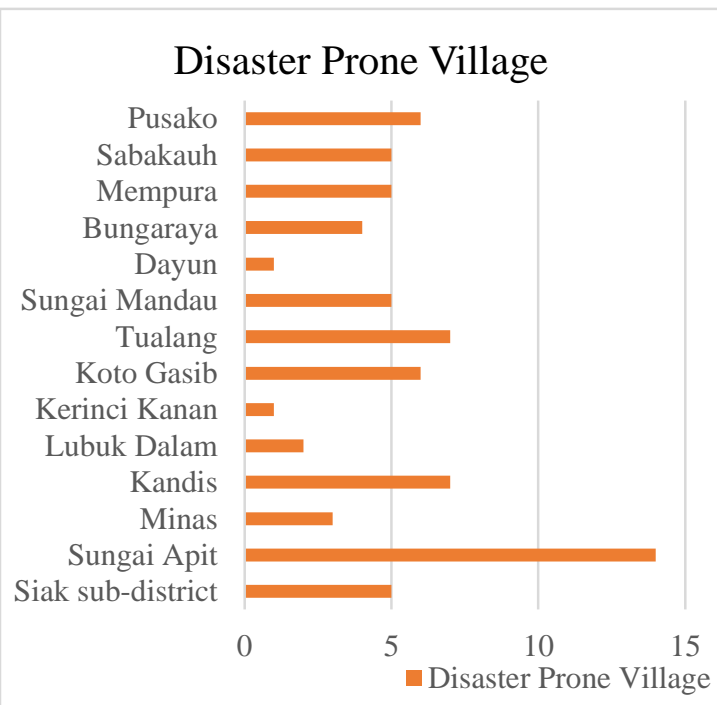

Table 1. Disaster Prone Village, Siak Regency

Based on the Regulation of the Director General of Forest Protection and Nature Conservation Number: P. 2 / Iv-Set / 2014, the Director General of Forest Protection and Nature Conservation, issued regulations related to the Formation and Development of Masyarakat Peduli Api. Masyarakat Peduli Api, hereinafter referred to as MPA, is a community that voluntarily cares for controlling forest and land fires who have been trained / provided with training and can be empowered to assist in forest fire control activities. Fires can be caused by several factors, including the dry season, the construction of canals on peat lands and human intentions in accelerating the opening of plantations. Based on the assumptions of rational choice theory, a person or actor's behaviour has a set of preferences to fulfil his wishes, the actor's behaviour is seen as material oriented and prioritizes personal interests [2].

Therefore, based on the Law in Indonesia, in the face of a disaster, it is necessary to have good disaster management; this is done to treat disaster risk as a priority. When natural disasters occur, effective disaster communication involving communication and information technology must be carried out especially from the government to the affected communities.

Before, during, and after major disasters, coordination of emergency response is an enormous problem due to the number of individuals and organizations involved in the response, issues with the interoperability of technology, impacts of the disaster on technologies used for communications, problems with adequate information sharing, and the lack of preexisting social networks in place to support community response, among others. "The disaster network is loosely structured, organizationally diverse, motivated by a broad range of interests, and in part ad hoc"[3].

In any emergency, the largest problems often derive from "collaborative problem solving" and other problems of coordination. Studies have repeatedly demonstrated the difficulties of coordination between responders, residents, government agencies, businesses, volunteers, and relief organizations in an emergency. Coordination in terms of information sharing, communication, and collaborative action present enormous social and behavioral problems for emergency response [4].

Major disasters are "occasions in which the boundaries between organizational and collective behavior are blurred" [5]. As a result, communication and coordination among residents and responders are among the most pressing issues in an emergency [6]. Conceptually, the preparation for responding to emergencies can be been seen as a cycle with information sharing and communication being key throughout the cycle [7] "Sharing information, willingness to collaborate, and shared values" are vital bases of effective information sharing and communication in major disasters [5]. Community response grids: Egovernment, social networks, and effective emergency management [4].

The dominant model of risk communication essentially is one of information transmission with the goal of educating the recipient to arrive at a rational understanding of the probable risks. The main concern is how to pass quantitative information about the probabilities and consequences of events from one information bearer (the transmitter) to another (the receiver) through a medium (the channel) with the minimum of distortion [8]. In fact, information transmission is only one part of communication which also involves developing shared meaning among individuals, institutions, and communities and establishing relationships of trust [9]. According to Breakwell [10], the main reason for communicating risks prior, during and after the natural disasters is to initiate and carry out direct protective measures. Masyarakat Peduli Api (MPA) is a disaster care community whose members from various professions have a concern for forest sustainability and for controlling forest and land fires voluntarily expressing their willingness to control according to their expertise and skills

\subsection{Community Based Disaster Management)}

The basic concept of community-based disaster management in Indonesia and as well in some countries is an effort to increase the capacity of communities to prepare for and cope with the result of a disaster. This is because the government has limited resources including human resources, funding, equipment and logistics. Because of that disaster management should be universality, involving all stakeholders, including government, private and public. All three of these components must be able to be equal actors, all must play a major role, not only play a role as well. The recovery 
from disaster can only be achieved through full participation of the affected communities.

The important thing that must be done is that Community Based Disaster Management requires community participation. That Public participation is a key factor in response to the disaster. In Law number 24 of 2007 on Disaster Management and Regulation of the National Disaster Management Agency No.13 of 2010 on the National Disaster Management Plan (Renas-PB) 2010-2014, and the Decree of the Head of the National Agency for Disaster Management No. 5 of 2010 on the National Action Plan for Disaster Risk Reduction (RANPRB) of 2010 to 1012 clearly states the importance of community participation, NGOs including international community. According Ali et.al. [11] Implementation of disaster management based community participation will lead:

(1) Disaster risk reduction with communities in disasterprone areas independently;

(2) Avoid the emergence of new vulnerabilities and dependency society in disaster-prone areas;

(3) Disaster risk management is an integral part of the development process and management of is ispinatural resources for the survival of life in disaster-prone areas; and

(4) Multi-sectoral approach, multidisciplinary and multicultural [11]

There have been various definitions of disaster proposed by scholars from different angles in different periods of time. Developing a definition of disasters contributes to better understanding of its theory and methodology. In the initial decades, disaster research was normally left to implicit or partial analysis of a disaster phenomenon. There exist numerous glossaries regarding disaster and related terms and concepts. Other scholars stressed the necessity for standardization of definitions to offer a steady structure for the reporting of events, collection of data and plan [12].

Scholars such as Carr (1932) recognized 'a disaster as a product of its consequences'. He argued 'if the walls withstand the earthquake and the dam retains the water, there is no disaster.' Instead, he views disaster as the 'collapse of the cultural protections' (Carr, 1932). The implied description suggests that disaster is any incident that produces substantial negative and undesirable consequences. [13].

Disaster is defined as an abrupt and calamitous incident that seriously disrupts the functions of a community or society. Such incident usually causes massive loss of human lives, his belonging and to the environment, which surpasses the community's capacity to manage using its own resources.
Disasters can be caused by nature and human actions. A disaster is said to have occurred when a hazard impacts vulnerable people. The combination of hazards, vulnerability and inability to reduce the potential negative consequences of risk results in disaster' [9].

\subsection{Disaster Communication Management}

Disaster Management can be defined as the organization and management of resources and responsibilities for dealing with all humanitarian aspects of emergencies, in particular preparedness, response and recovery in order to lessen the impact of disasters [11]. According to Coppola and Maloney [14] that modern disaster management comprehensively includes four functional components, namely: (1). mitigation which includes the reduction or elimination of hazard risk components, (2). Preparedness, which includes preparing communities at risk from disasters or preparing communities to be able to help people in disaster events with a variety of tools / equipment to improve their ability to survive and minimize financial risks and other risks. (3). Response includes actions taken to reduce or eliminate the impact of disasters, and (4). Recovery, including repairing, reconstructing or recovering what has been damaged / lost as part of a disaster. These four important aspects in disaster management are things that must be done to reduce the greatest risk from the disaster.

Shaw and Gupta [14] that the communication aspect in disaster management plays an important role. In the disaster management cycle aspects of communication are also needed. Before the disaster occurred the communication aspects related to providing accurate information, coordination and aspects of cooperation, especially to people who are vulnerable to disaster events. The activities that can be carried out are prevention and risk reduction activities such as preparedness to face likely disaster, dissemination of early warnings. When disaster strikes, communication, information, collaboration and coordination are the keys to success in disaster management. The various activities that can be carried out are quick response, provision of relief, mobilization of search \& rescue, your damage assessment. In the post disaster situation the communication aspect is also needed during the reconstruction and recovery after the disaster situation. This is as illustrated in the following chart:

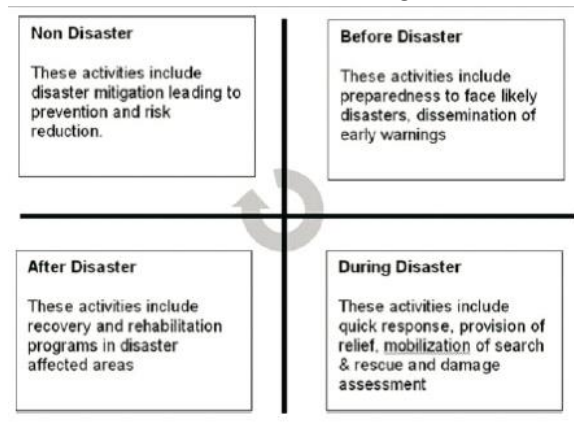

Figure 1. Communication Reconstruction Aspects 
During and after a disaster, communication is an important thing to do, especially from the government to the affected communities. In this case, at the time of occurrence and post-disaster the need for accurate information is needed by the community and private institutions that have concern for disaster victims. Communication in disasters is not only needed in disaster emergency conditions, but is also important at the time and pre-disaster. As said that communication is the best way to succeed in disaster mitigation, preparation, response, and recovery of a situation during a disaster. The ability to communicate messages about disasters to the public, government, media and opinion leaders can reduce risk, save lives and the impact of disasters [15]

One of a crucial challenge in responding to natural disasters is communication. Communication during and in the aftermath of disaster is a vital aspect of response and recovery initiatives. Thorough communication disaster victims connect with first responders, support systems and other family members. As such, having a dependable and accessible communication and information systems also are vital to a community's resilience [16]. This importance was clearly highlighted in disasters such as Hurricane Katrina and the 9/11 terrorist attacks [17]. Many disaster scholars have recognized a substantial rise in the demand for information on both affected and unaffected communities in disasters [18]. In fact, it would not be an understatement to say that there is a frenzy to seek information from surviving victims, their family and friends, and interested stakeholders such as the various disaster response agencies. Therefore, to satisfy the demand for information, often people seek information from the mass media, persons who seem to have authority, local government authorities or other community members as the main source of information during disaster response phase [19].

However, one can argue the validity of information provided by the community members. Community members lack the mechanism to aggregate and authenticate information, thus such communication cannot be automatically recognized as formal said Austin et al. and Johnson on Moorthy. Gultom, Palen \& Liu on Moorthy [19] tell if these information lacuna generates demands for continual organizing, monitoring of credibility, and added verification, so that to establish and disseminate reliable disaster communication for the information seekers. Nonetheless, information seeking is likely to have a positive result through engaging local individuals as sources of information, compared to mass media. In situations when information appears in bits and pieces, scarce, or even botched, affected communities are inclined to merge and join with others as their reliable information sources [19].
According Muryanma et.al on Moorthy [19], In disaster communication, the trust and trust building is a necessary pre-requisite for prompt decision making in crisis situations. In disasters, trustworthiness of information is essential for effective disaster response actions. Affected people rely on information that they perceive as trustworthy. It is unlikely that they will pay much attention and act on certain information given by someone they lack trust in a situation that will avert the transformation of the given information into usable knowledge [4]. Trust helps to increase the worthiness of the information in the eye of the affected people, and in increasing the whole quality of the communication process, and in the efficiency of information seeking process [19].

Usually in disasters, Borgatti \& Halgin said if humanitarian agencies (many of international origins) play critical roles, not only in providing material and socio-psychological support to affected persons, but also provide vital specialized technical support to local teams in disaster rescue initiatives. However, due to the foreign origin and perhaps for the lack of knowledge in local knowledge, customs and sensitivities humanitarian agencies frequently face problems in creating trust within the affected community [19].

Developing trust is a long-term and enduring process that requires a relationship with the targeted groups of people. However, disasters do come unannounced, and humanitarian agencies usually go into the disaster affected areas shortly after a disaster has occurred, often without much knowledge about the target communities that they are dealing with. Thus, several researcher said if to bridge this knowledge gap, these humanitarian agencies ought to involve local support agencies, as they will be better suited to identify suitable local knowledge to quicken the process of trust building [19].

Disaster Management, must be supported by various approaches both soft power and hard power to reduce the risk of disasters. The soft power approach is to prepare community preparedness through the dissemination and provision of information about disasters. While hard power is an effort to deal with disasters with physical development such as building facilities and infrastructure.

\section{METHOD}

In accordance with the type of qualitative research and data sources required, the data collection technique in case study research is to use data collection techniques such as in depth interviews, Focus Group Discussion (FGD) and document analysis (content analysis) [20]. Data collection techniques in this study, researchers used several ways, namely: 


\subsection{In-depth Interview}

In-depth interview (in depth interviewing) is a meeting of two people to exchange information and ideas through question and answer so that they can construct meaning in a particular topic [21]. The research informants consisted the Regional Disaster Management Agency (BPBD) of Siak and Masyarakat Peduli Api (MPA). In this study using two interview techniques, namely structured interviews (structured interviews) and unstructured interviews (unstructured interviews).

\subsection{Focus Group Discussion (FGD)}

The implementation of the Focus Group Discussion (FGD) is by selecting key informants and inviting to discuss research issues, FGD participants have an equal position and there are no authority holders in the FGD group so that the discussion of the questions asked can take place freely and openly.

The data in this study will be analysed qualitatively. Qualitative research is a procedure that produces descriptive data in the form of written words, or oral people or observed behaviour [22]. During data collection, researchers move interactively in 3 components of analysis, namely data reduction, data presentation and final conclusions / verification [23].The interactive analysis model is an analysis model that consists of three components, namely data reduction, data presentation and conclusion drawing [24]. The components of the interactive analysis model can be explained as follows:

\subsubsection{Data Reductions}

It is a process of selecting, focusing, simplifying and abstracting the raw data contained in the field notes relating to the synergized communication Model of Regional Disaster Management Agency (BPBD) and MPA for Disaster Communication on Forest and Land Fires in Siak District, Riau. Document Review (content analysis) Documentation is the activity of collecting data by Regional Disaster Management Agency (BPBD) and MPA policy of the Siak Regency who related to the mitigation of the Forest and Land Fires in Siak District, Riau.

\subsubsection{Data Display}

This Is an assemblage of information organizations that allows research conclusions. In this case the display includes various types of matrices, images, tables, schemes and tables related to the role of Masyarakat Peduli Api (MPA) Communities in Forest and Land Fire Disaster Communication in Riau Province.

\subsubsection{Conclusion Drawing}

Is an organization of data that has been collected so that conclusions can be made regarding the Role communication model of MPA for the Forest and Land Fires in Siak, Riau Regency, Indonesia.

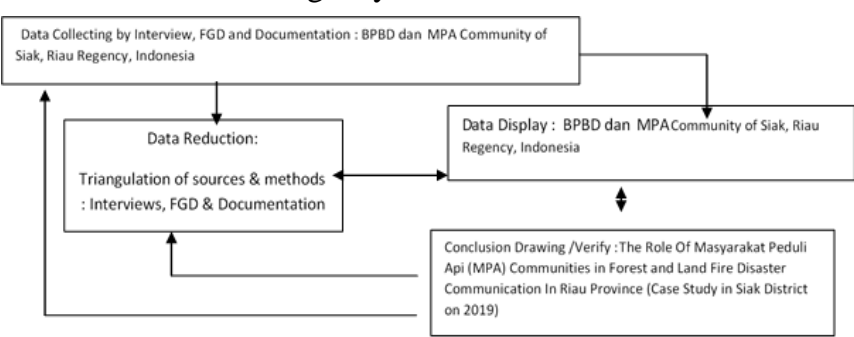

Figure 2. Interactive Analysis Method Research of The Role of Masyarakat Peduli Api (MPA) Communities in Forest and Land Fire Disaster Communication in Riau Province (Case Study in Siak District in 2019)

Source: Researcher \& Adapted from Miles \& Huberman

At the time the researchers compiled field notes on various matters relating to the role communication model of Regional Disaster Management Agency (BPBD) and Masyarakat Peduli Api (MPA) on Forest and Land Fires in Siak, Riau Regency, Indonesia. After that researchers began to make temporary conclusions, because the data collection process is still ongoing. Data collection and analysis go hand in hand so that the analysis process occurs interactively and tests between components which as a whole are cyclical in nature and last for quite a long time. By using this analysis technique, the conclusions regarding the role communication model of Masyarakat Peduli Api (MPA) and BPBD on Forest and Land Fires in Siak, Riau Regency, Indonesia can be tested accurately.

\section{RESULT AND DISCUSSION}

The problem of forest fires often takes its toll and at unexpected times. The causes of forest fires are various and arise due to areas prone to forest fires, namely because peat lands are prone to fires, causing the number of fires to increase. However, it is important that the government plays a role and cooperation with the surrounding community to reduce the loss rate for natural disasters. The Siak Regency Government, Riau, has formed a community to play a role in controlling forest fires, namely Masyarakat Peduli Api (MPA). Masyarakat Peduli Api (MPA) A disaster care community whose members are from various professions who are concerned about forest sustainability and forest and land fire control by expressing their willingness to exercise control with their expertise and skills.

Masyarakat Peduli Api (MPA) Community has an important role and duty in efforts to control forest and land fires. As explained in the Regulation of the Director General of Forest Protection and Nature Conservation Number: P. 2 / IV-SET / 2014. In carrying out this task, 
people who care about fire are required to work actively, voluntarily and responsibly. The goal is that the problems of forest and land fires in the village area can be controlled and resolved.

Based on field data from BPBD Secretary Siak Regency, Mr. Arif Hamidi, S.Sos., M.Si, the Siak Regency Government embraces Masyarakat Peduli Api (MPA) Community as an extension of the community in handling forest fires in Siak, both before and after the disaster.

"In disaster management BPBD Kabupaten Siak explained the supporting factors in carrying out the mechanism by carrying out two-way and two-function communication. The exit function is by providing information or messages in accordance with the policy direction and objectives of the local government towards the interests of the community as the target audience". (Arif Hamidi, S.Sos., M.Si, Head Secretary of BPBD Siak Regency)

When the forest fire disaster occurred in Siak District in 2019, the Masyarakat Peduli Api (MPA) had an important role in communicating disasters. The Role of the Masyarakat Peduli Api (MPA) as conveyed to the Masyarakat Peduli Api (MPA) in the following interview:

"Whereas the role of MPA when a disaster occurs is as an extension of the government in the community, because MPA comes from the community and its role is very important, namely by providing information regarding the location of forest fires, disseminating information to village communities about forest fire disaster mitigation and the impact of forest fires. Forest fires and conducting counseling, training and simulating forest fire disasters to the community with BPBD related to disaster mitigation and introduction to the use of firefighting equipment". (Febry Yani, Team of Masyarakat Peduli Api (MPA) Community).

Thus the Masyarakat Peduli Api (MPA) has an important role in disaster communication to the community and can minimize the loss of casualties and material and immaterial losses as a result of the forest fires that occur. The people of Siak Regency are aware of the potential for disasters that occur because they live in areas prone to forest fires. With the information submitted by the Siak Regency BPPD and followed up directly by the Masyarakat Peduli Api (MPA), the Community related to the location of burned forestland, an understanding of the dangers and negative impacts of forest fires and the community's understanding of the use of fire extinguishers independently.

Nevertheless, several inhibiting factors occur during disaster management, such as the lack of public awareness to participate in the socialization of disaster management measures, as well as the socialization of applicable regional regulations. In addition, according to
Marnelly's study on the Barriers to Implementation The role of the absence of work insurance makes MPA personnel not dare to take risks when doing fire fighting tasks on burning land. Meanwhile, $8.7 \%$ of MPA personnel stated that the lack of cohesiveness of MPA personnel had also affected the work productivity of MPA personnel in the field. So that when the fire broke out, not all personnel took to the field. The relationship that is not good between MPA personnel causes the implementation of tasks in the field to be disrupted [2].

Masyarakat Peduli Api (MPA) have carried out disaster mitigation by providing information both online and traditionally, especially for people who are vulnerable to disaster events. Activities that can be carried out are prevention and risk reduction activities, such as disaster preparedness and early warning dissemination. When a disaster occurs, Communication, Information, Collaboration and Coordination (KIKK) is the key to success in disaster management. Various activities that can be carried out are quick response, assistance, SAR mobilization and damage assessment. In this case, a quick response has been carried out with the synergy of Masyarakat Peduli Api (MPA) Community and BPBD of the Siak Regency Government by helping to provide information, education and persuasion for forest and land fire disaster mitigation in Siak Regency, Riau, Indonesia.

From this discussion, the result can be drawn that through community-based communication, disaster communication will be more effective, this is because they return to the principles of society for society, because they are based on community-based participants in accordance with the opinion of Ali et.al. [11] that Implementation of disaster management based community participation will lead (1) Disaster risk reduction with communities in disaster-prone areas independently; (2) Avoid the emergence of new vulnerabilities and dependency society in disaster-prone areas; (3) Disaster risk management is an integral part of the development process and management of natural resources for the survival of life in disaster-prone areas; and (4) Multi-sectoral approach, multidisciplinary and multicultural [11]. This means that the Fire Care Community (MPA) will certainly have an effective role because they communicate to their fellow residents there.

Besides that, MPA also has an integral part of the culture, knowledge and local wisdom that is there so that risk reduction can be applied. Apart from that it is multisectoral and community, so that they understand and know local wisdom, local people's habits can be understood so that their communication can be assessed effectively. This is also supported by the statement of a Scholars such as Carr (1932) who stated that recognized 'a disaster as a product of its consequences' and this is in line with the fact that in order to communicate effectively they must implement consequences in the form of 
protecting locations in closer areas. and know local wisdom

\section{CONCLUSION}

At the time of the forest fire disaster in Siak district on August, 10th 2019. Siak Regency BPPD in collaboration with MPA have carried out Communication, Information, Coordination and Communication, Information, Coordination and Cooperation (KIKK) activities with agencies related to forest and land fires. In this case, MPA has an important role including (1). Providing information related to the location of the incident, (2).Disseminating information to village communities regarding forest fire disaster mitigation (prevention) and the impact of forest fires, and (3). Conducting education, training and disaster simulations forest fires to the community with BPBD related to disaster mitigation and the introduction of the use of forest fire fighting equipment. When the forest fire occurred, MPA acted as an extension of the hands of the government of Siak Regency, Riau, Indonesia and synergized effective communication between the government and the people of Siak Regency, Riau through MPA. MPA is a supporting factor in forest fire disaster management in Siak Regency, in conveying disaster communication messages from the government to the people of Siak Regency, Riau, Indonesia can quickly and accurately reach and information related to calls for refuge in safe areas, even though there are still obstacles. The result can be drawn that through community-based communication, disaster communication will be more effective, this is because they return to the principles of society for society, because they are based on community-based participants. This means that the Fire Care Community (MPA) will certainly have an effective role because they communicate to their fellow residents there.

\section{ACKNOWLEDGMENTS}

The author would like to thank the Ministry Of Research And Technology / Research Agency And National Innovation The Directorate of Research and Community Service (DRPM) which has provided research funding in accordance with Agreement / Contract Number 227 / SP2H / LT / DRPM / 2019 dated March 11, 2019, the 2019 National Strategic Competitive Grant Research scheme which is the basis for writing this article. The author also thanks the Chancellor of the Muhamamdiyah University of Yogyakarta and the Research Institute for Development and Community Service (LP3M), as well as the Regional Disaster Management Agency (BPBD) and the Masyarakat Peduli Api (MPA) who participated as informants in this research. Thanks to all those who helped with this research.

\section{REFERENCES}

[1] Tirto.Id (2019). "Kebakaran Lahan Dan Hutan Di Riau Meluas, Capai 841 Ha Pada 2019", Retrieved From Https://Tirto.Id/Kebakaran-Lahan-DanHutan-Di-Riau-Meluas-Capai-841-Ha-Pada-2019Dhhc)

[2] Marnelly, T. R (2018). Lembaga Masyarakat Peduli Api : Studi Tentang Hambatan Pelaksanaan Peran. Jurnal Atropologi .Vol. 20 (2) 223 - 230.

[3] Waugh, W. L., \& Sylves, R. T. (2002). Organizing The War On Terrorism. Public Administration Review, 62, 145-153.

[4] Jaeger, P.T, Et.Al. 2007. Community Response Grids : E-Government, Social Networks, And Effective Emergency Management. Journal Elsevier.

[5] Kapucu, N. (2004). Interagency Communication Networks During Emergencies: Boundary Spanners In Multiagency Coordination. American Review Of Public Administration, 36, 207-225.

[6] Haddow, G. D., \& Bullock, J. A. (2003). Introduction To Emergency Management. Newton, PA: Buttersworth-Heinemann.

[7] Pelfrey, W. V. (2005). The Cycle Of Preparedness: Establishing A Framework To Prepare For Terrorist Threats. Journal Of Homeland Security And Emergency Management, 2(1), 1-21.

[8] Kasperson, R.E., Renn, O., Slovic, P., Brown, H.S., Emel, J., Goble, R., Kaperson, J.X., \& Ratick, S. (1988). The Social Amplification Of Risk: A Conceptual Framework. Risk Analysis, 8(2), 177187

[9] Tansey, J \& Rayner, S. 2010. Handbook Risk And Crisis Communications. Routledge Handbook Online. Retrieved From Routledgehandbooks.Com/Doi/10.4324/97802038 91629.Ch3. Access On June, 152020.

[10] Rod,S.K., Botancarl, Holen. 2012. Are Risk Communication And The Willingness To Follow Evacuation Instructions In A Natural Disaster, Journal Of Health, Risk \& Society, Vol. 14, No. 1

[11] Ali, M S S, Et.Al. (2019). Community Based Disaster Management: Indonesia Experience. IOP Publishing : Series: Earth and Environmental Science.

[12] Mayner, L. \& Arbon, P. (2015). Defining disaster: the need for harmonization of terminology. Australian Journal of Disaster and Trauma Studies, 19, 21-25.

[13] Perry, Ronald W. (2017). Defining Disaster: An Evolving Concept. Handbook of Disaster Research, 3-22.

[14] Coppola, Damon, Maloney, Erin K, 2009. Emergency Preparedness Strategies for Creating a 
Disaster Resilient Public. Taylor and Francis Group, LLC.

[15] Haddow, G. D, dan Kims. 2008. Disaster Communications, In A Changing Media World. London. Elsevier

[16] The Associated Press-NORC Center for Public Affairs Research. (2013). Communication during disaster response and recovery. Retrieved from http://www.apnorc.org/PDFs/Resilience\%20in\%20 Superstorm\%20Sandy/Communicatio ns_Final.pdf

[17] Dwyer, J. (2006, April 1). The calls: 911 tapes echo grim struggle in towers. New York Times.

[18] Ferrante, P. (2010). Risk \& crisis communication. Professional Safety, 55(6), 38-45.

[19] Moorthy, R, Benny G, Gill, S. S. (2018). Disaster Communication in Managing Vulnerabilities. Jurnal Komunikasi Malaysian Journal of Communication 34 (2), 51-66

[20] Cresswell, J.W. 2012. Research Design: Qualitative, Quantitative and Mixed Approaches. Third Edition. Yogyakarta: Pustaka Pelajar

[21] Sugiyono. 2005. Qualitative Research , Bandung: Penerbit CV Alfabeta

[22] Moleong, Lexy J. 2003. Qualitiative Research Method. Bandung : Rosdakarya.

[23] Sutopo, H.B, 2006. Qualitative Research Methodology: Basic Theory and Its Application in Research, Surakarta: Sebelas Maret University Surakarta.

[24] Miles \& Huberman. A,M. 1984. Qualitiatve Data Analysis : A Sourcebook of New Methods, London : Sage Publication 